\title{
Shoot Formation and Plant Regeneration of Vegetative Pear Buds Cryopreserved at $-150^{\circ} \mathrm{C}$
}

\author{
Mitsuteru Suzuki ${ }^{1}$, Takao Niino ${ }^{2}$, Tomoya Akihama ${ }^{1}$ and Seibi Oka ${ }^{3}$ \\ ${ }^{1}$ Faculty of Agriculture, Meiji University, Kawasaki, Kanagawa 214 \\ ${ }^{2}$ Tohoku National Agricultural Experiment Station, Fukushima, Fukushima 960-21 \\ ${ }^{3}$ National Institute of Agrobiological Resources, Tsukuba, Ibaraki 305
}

\begin{abstract}
Summary
Vegetative winter buds of pear (Pyrus communis $\mathrm{L}$. cv. Beurré d'Amanlis) were successfully cryopreserved at $-150{ }^{\circ} \mathrm{C}$ after pre-freezing to $-30{ }^{\circ} \mathrm{C}$. Meristems were excised from the buds and cultured on medium (WPM) containing $1.0 \mathrm{mg} \cdot$ liter $^{-1} 6$-benzylaminopurine (BA), $25 \mathrm{~g} \cdot$ liter $^{-1}$ sucrose and $0.8 \%(\mathrm{w} / \mathrm{v})$ agar. Partial dehydration at $25{ }^{\circ} \mathrm{C}$ prior to pre-freezing at $-30{ }^{\circ} \mathrm{C}$ improved the subsequent shoot formation rate. The optimal water content of the dehydrated buds was about $41 \%$. Pre-freezing with a daily decrease at $5{ }^{\circ} \mathrm{C}$ increments to $-30{ }^{\circ} \mathrm{C}$ followed by slowly thawing in air at $0{ }^{\circ} \mathrm{C}$ was effective for producing the highest rate of shoot formation. Micrografting of the cryopreserved vegetative buds on young seedlings also induced normal shoot growth. This procedure was successfully applied to twelve other cultivars of pear. Thus, this protocol of using vegetative buds is a simple, reliable method for cryopreserving pear germplasm.
\end{abstract}

\section{Introduction}

Pear (Pyrus species) is an important horticultural germplasm grown widely around the world. Cryopreservation of plant cells, tissues, and organs, such as the vegetative dormant buds, is a practical means of long-term storage and conservation of plant genetic germplasm.

Sakai (1960) first demonstrated that winter-hardy twigs survived immersion into liquid nitrogen (LN), if they were previously freeze-dehydrated to -20 or $-30{ }^{\circ} \mathrm{C}$. Pre-frozen willow twigs stored in $L N$ for 1 year retained their viability and developed roots and shoots (Sakai, 1960). This method was successfully applied to several winterhardy fruit trees. It was also demonstrated that pre-frozen apple buds stored in LN for 1 year developed normal shoots after being micrografted onto rootstocks (Sakai and Nishiyama, 1978).

There are several advantages to cryopreservation using vegetative buds: clonal integrity is maintained, the method is simple, reliable, and space-efficient, it requires no expensive, sophisticated cooling apparatus; very long storage is

Received; June 7, 1996. Accepted; September 2, 1996. theoretically possible; and it avoids possible toxic effects of chemical cryoprotectants, which are in. dispensable for conventional methods (Stushnoff, 1987; Niino et al., 1991).

Moriguchi et al. (1985) reported that pre. freezed shoot apices of vegetative buds of pear could survive after storage in LN. Oka et al. (1993) successfully cryopreserved vegetative buds of pear by a gradual freezing to $-40{ }^{\circ} \mathrm{C}$, immer. sion in $\mathrm{LN}$, and then thawing at $37{ }^{\circ} \mathrm{C}$ in water, but the rate of normal shoot formation following cryopreservation was only $50 \%$.

This study was carried out to develop an improved method for inducing a higher rate of shoot formation from cryopreserved vegetative buds of pear attached to shoot pieces.

\section{Materials and Methods}

\section{Plant materials}

Shoots were collected from 7-year-old pear (Pyrus communis L., 'Beurré d'Amanlis') plants in February, when buds were in quiescence, in a field of Tohoku National Agricultural Experiment Station, Shinjo, Yamagata, 996 Japan. Twelve other pear cultivars were Pyrus communis L., 
'Beurré d'Anjou', 'Docteur Jules Guyot', 'Joséphine de Malines', 'Lincoln', 'Seigneur d'Esperen', 'Stark. ing Delicious', P. pyrifolia Nakai 'Amanogawa', 'Hougyoku', 'Nishichikuma A', 'Shinkou', 'Wasetaichou', and P. pashia D. Don. 'Nepal pear A'. The samples were wrapped in a polyethylene film, stored at $5{ }^{\circ} \mathrm{C}$, and used within one month after collection.

\section{Partial dehydration and pre-freezing conditions}

Axillary vegetative buds were excised together with about $5 \mathrm{~mm}$ of twig vascular tissue are partially dehydrated to a water content of $20 \%$ in air at $25{ }^{\circ} \mathrm{C}$ prior to pre-freezing. The dry weight of the buds was determined by heating them at 110 ${ }^{\circ} \mathrm{C}$ for $16 \mathrm{hr}$. About 20 pieces of the dehydrated buds were put into a polypropylene tube $(50 \mathrm{~mm}$ length) and held at $0{ }^{\circ} \mathrm{C}$ for 1 day. These buds were pre-frozen from $0{ }^{\circ} \mathrm{C}$ to $-20{ }^{\circ} \mathrm{C}$ by successively transferring the tubes at $5{ }^{\circ} \mathrm{C}$ increments daily and chilling to $-30{ }^{\circ} \mathrm{C}$ or $-40^{\circ} \mathrm{C}$ in $10^{\circ} \mathrm{C}$ increments daily.

\section{Cooling at $-150^{\circ} \mathrm{C}$, thawing and shoot regeneration}

The pre-frozen buds were cooled to $-150{ }^{\circ} \mathrm{C}$ by transferring the tubes to an ultra-cold freezer (SANYO, MDF-1155 AT) and held there for at least 1 month. The buds were then thawed either slowly at $0^{\circ} \mathrm{C}$ in air (more than $2 \mathrm{hrs}$ ) or rapidly in a water bath at $37{ }^{\circ} \mathrm{C}$ for $5 \mathrm{~min}$. The thawed buds were surface-sterilized with $70 \%(\mathrm{v} / \mathrm{v})$ ethanol for $1 \mathrm{~min}$, sodium hypochlorite solution $(0.5 \%$ effective chlorine concentration) for $15 \mathrm{~min}$, and rinsed three times with sterile distilled water. Apical meristems, $1 \mathrm{~mm}$ in diameter, were excised from dormant buds and placed on WPM (Lloyd and McCown, 1980) containing $1.0 \mathrm{mg} \cdot \mathrm{liter}^{-1} \mathrm{BA}$, $25 \mathrm{~g} \cdot$ liter $^{-1}$ sucrose and $0.8 \%(\mathrm{w} / \mathrm{v})$ agar. The cultures were maintained at $25^{\circ} \mathrm{C}$ under a $16 \cdot \mathrm{hr}$. day $^{-1}$ photoperiod $\left(52 \mu \mathrm{mol} \cdot \mathrm{s}^{-1} \cdot \mathrm{m}^{-2}\right)$. Alternatively, the buds with approximately $3-4 \mathrm{~mm}$ of vascular tissues, excised from the cryopreserved vegetative winter buds, were micrografted onto seedlings to test their regeneration ability. The rate of shoot formation was defined as the percent of shoot tips producing normal shoots 50 days after grafting.

\section{Results and Discussion}

In this study, an ultra-cold freezer at $-150{ }^{\circ} \mathrm{C}$ was used for cryopreservation instead of $L N$.
Cryopreservation in an ultra-cold freezing unit is easier, safer, and less costly than cryopreservation using a container of $L N$.

The effect of partial dehydration prior to prefreezing on the rates of shoot formation of vegetative buds stored at $-150^{\circ} \mathrm{C}$ is shown in Table 1 . Partial dehydration of the vegetative buds significantly improved the rate of shoot formation $(P<$ 0.05 ), reaching a maximum of $88.6 \%$ at about $41 \%$ water content. The water content of the apical meristem $2 \mathrm{~mm}$ long excised from the dehydrated vegetative buds was about $40 \%$ before prefreezing. In vegetative dormant buds with less than $41 \%$ water content, the rate of shoot formation decreased significantly, because the meristems were excessively dehydrated and injured.

For successful cryopreservation, it is important to avoid lethal intracellular freezing (Sakai, 1993). Dehydration of flower buds by wind at $0{ }^{\circ} \mathrm{C}$ enhanced the supercooling ability of Rhododendron florets in intact buds. Water migration within flower buds was observed with some variation, in the ice formation sites and the quantity of migrat. ing water (Ishikawa and Sakai, 1981). The dehydration of vegetative apple buds at $-4{ }^{\circ} \mathrm{C}$ to $20 \%$ to $30 \%$ water content significantly enhanced the shoot survival rate (about 70\%) following cryopreservation (Tyler and Stushnoff, 1988). It was pointed out that as water content decreased to about $25 \%$, the survival rate following cryop-

Table 1. Effect of partial dehydration on shoot formation of shoot tips of 'Beurré d'Amanlis' pear stored at $150^{\circ} \mathrm{C}$.

\begin{tabular}{cc}
\hline \hline Water content (\%) & Shoot formation $(\% \pm$ S. E.) \\
\hline $61^{*}$ & $66.8 \pm 7.0^{\mathrm{b}}$ \\
48 & $80.1 \pm 2.3^{\mathrm{ab}}$ \\
41 & $88.6 \pm 5.3^{\mathrm{a}}$ \\
34 & $64.2 \pm 4.2^{\mathrm{b}}$ \\
20 & $5.3 \pm 5.2^{\mathrm{c}}$ \\
\hline
\end{tabular}

After partial dehydration, vegetative buds were pre-frozen to $-20^{\circ} \mathrm{C}$ in $5^{\circ} \mathrm{C}$ steps at daily intervals and then frozen at $-30^{\circ} \mathrm{C}$ for 1 day. Pre-frozen buds at $-30^{\circ} \mathrm{C}$ were transferred to an ultra-cold freezer at $-150^{\circ} \mathrm{C}$. Cryopreserved buds were slowly thawed in air at $0^{\circ} \mathrm{C}$. After sterilizing, shoot tips were excised and placed on WPM containing $1.0 \mathrm{mg} \cdot \mathrm{liter}^{-1} \mathrm{BA}$ and $25 \mathrm{~g} \cdot \mathrm{liter}^{-1}$ sucrose. Approximately 20 buds were treated for each of two replicates.

a. b. c Significantly different at $P<0.05$, respectively (Duncan's new multiple range test).

* Original water content of vegetative winter bud. 
reservation increased (Tyler et al., 1988). In this study, dehydration at $25{ }^{\circ} \mathrm{C}$ prior to pre-freezing at $-30{ }^{\circ} \mathrm{C}$ was effective for normal shoot forma. tion following cryopreservation. In general, the procedure for cryopreservation using vegetative dormant buds has a problem because the season for collecting these materials is limited (Niino, 1993). Seasonal ultrastructural changes in cortical cells of apple twigs were studied by Kuroda and Sagisaka (1993). During cold acclimation, the most striking changes were microvacuolation and augmentation of the volume of the cytoplasm. Thus, it is thought that the survival of vegetative buds following cryopreservation is related to ultrastructural changes in cells during cold acclimation, and the most important factor is a change in the internal water content of the cells. Partial dehydration up to about $38.5 \%$ of the vegetative mulberry buds from shoot tips collected from late autumn to early spring improved the recovery rate following cryopreservation (Niino, 1993). These results show that partial dehydration of vegetative buds prior to pre-freezing is a significant factor for nor-

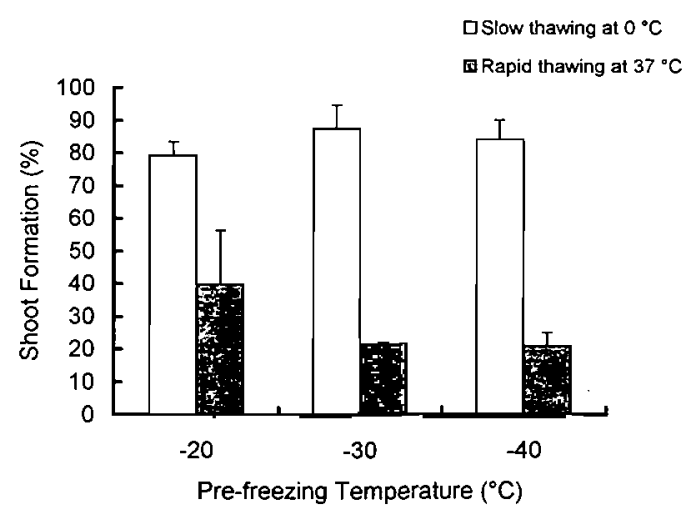

Fig. 1. Effect of pre-freezing temperature on the rate of shoot formation of vegetative buds of 'Beurré d'Amanlis' pear stored at $-150{ }^{\circ} \mathrm{C}$. Vegetative buds were partially dehydrated to $40-41 \%$ water content at $25^{\circ} \mathrm{C}$. These buds were pre-frozen to $-20{ }^{\circ} \mathrm{C}$ in $5{ }^{\circ} \mathrm{C}$ increment daily and then chilies further to $30{ }^{\circ} \mathrm{C}$ or $-40{ }^{\circ} \mathrm{C}$ in $10{ }^{\circ} \mathrm{C}$ steps daily. Pre-frozen buds were directly transferred to an ultra-cold freezer at $-150{ }^{\circ} \mathrm{C}$. Cryopreserved buds were slow. ly thawed in air at $0{ }^{\circ} \mathrm{C}$ or rapidly thawed in water at $37{ }^{\circ} \mathrm{C}$. After sterilization, shoot tips were excised and placed on WPM containing $1.0 \mathrm{mg} \cdot \mathrm{liter}^{-1} \mathrm{BA}$. Approximately 20 buds were treated for each of two replicates. mal shoot regeneration following cryopreservation.

Pre-freezing and thawing temperatures considerably affect the shoot formation rate. The highest rate of shoot formation was obtained by pre-freez. ing at $-30{ }^{\circ} \mathrm{C}$ followed by slow thawing at $0{ }^{\circ} \mathrm{C}$ (Fig. 1). This result agrees with those obtained with other woody plants. For example, a high rate of shoot formation following cryopreservation of vegetative mulberry buds was obtained by prefreezing at $-30{ }^{\circ} \mathrm{C}$ followed by slow thawing at 0 ${ }^{\circ} \mathrm{C}$ (Yakuwa and Oka, 1988). In the case of apple, the highest survival rate of cryopreserved vegetative buds was obtained by pre-freezing at $-30{ }^{\circ} \mathrm{C}$ and slow thawing at $2{ }^{\circ} \mathrm{C}$ for $24 \mathrm{hrs}$ (Tyler and Stushnoff, 1988).

Using the best method for maximizing the rate of shoot formation of 'Beurré d'Amanlis', with 12 other pear cultivars, shoot formation of 60 to $92 \%$ was obtained (Table 2).

Successfully cryopreserved pear shoot tips resumed growth in 7 days after re-culturing and de-

Table 2. Shoot formation rate of excised shoot tips from vegetative buds of 12 pear cultivars stored at $150^{\circ} \mathrm{C}$.

\begin{tabular}{lc}
\hline \multicolumn{1}{c}{ Cultivar } & $\begin{array}{c}\text { Shoot formation } \\
(\% \pm S . \text { E. })\end{array}$ \\
\hline Pyrus communis L. & \\
cv. Beurré d' Anjou & $79.7 \pm 14.7$ \\
cv. Docteur Jules Guyot (Precoce) & $66.6 \pm 4.0$ \\
cv. Joséphine de Malines & $92.1 \pm 2.0$ \\
cv. Lincoln & $55.5 \pm 5.5$ \\
cv. Seigneur d' Esperen & $78.9 \pm 0$ \\
cv. Starking Delicious & $59.2 \pm 9.2$ \\
Pyrus pyriforia Nakai & \\
cv. Amanogawa & $92.5 \pm 2.5$ \\
cv. Hougyoku & $87.0 \pm 8.1$ \\
cv. Nishichikuma A & $72.5 \pm 2.5$ \\
cv. Shinkou & $75.8 \pm 0.8$ \\
cv. Wasetaichou & $69.5 \pm 0.5$ \\
Pyrus pashia D. Don. & \\
cv. Nepal pear A & $85.5 \pm 5.0$ \\
\hline
\end{tabular}

Vegetative pear buds were partially dehydrated to $40 \sim$ $41 \%$ water content at $25^{\circ} \mathrm{C}$. These buds were pre-frozen to $-20^{\circ} \mathrm{C}$ in $5^{\circ} \mathrm{C}$ increment daily and then chilled further to $30^{\circ} \mathrm{C}$ for 1 day before being transferred to an ultra-cold freezer at $-150^{\circ} \mathrm{C}$. Pre frozen buds were transferred to an ultra-cold freezer at $-150^{\circ} \mathrm{C}$, and then slowly thawed in air at $0^{\circ} \mathrm{C}$. After sterilizing, shoot tips were excised and placed on WPM containing $1.0 \mathrm{mg} \cdot$ liter $^{-1} \mathrm{BA}$ and $25 \mathrm{~g} \cdot$ liter $^{-1}$ suc. rose. Approximately 20 buds were treated for each of two replicates. 
veloped normal shoots within 14 days without callus formation. A shoot formed from the cryopreserved shoot tip after 30 days of reculture is shown in Fig. 2. Almost all shoots grew normally on WPM containing $1 \mathrm{mg} \cdot \operatorname{liter}^{-1} \mathrm{BA}$ and 25 $\mathrm{g} \cdot$ liter $^{-1}$ sucrose.

Shoot formation of excised shoot tips from vegetative buds stored at various temperatures were also examined. There were no significant differences in the rate of shoot formation among buds stored at $-135{ }^{\circ} \mathrm{C},-150{ }^{\circ} \mathrm{C}$ and $-196{ }^{\circ} \mathrm{C}$ for one month (Table 3 ).

Because time is required to regenerate flowering plants from meristem cultures, we examined the micrografting technique of cryopreserved vegetative buds as an alternative method. The excised buds attached to vascular tissue (3 to $4 \mathrm{~mm}$ ), which were directly micrografted onto seedlings, regenerated normal shoots after 2 months (Fig. 3). The average recovery rate of plants from frozen
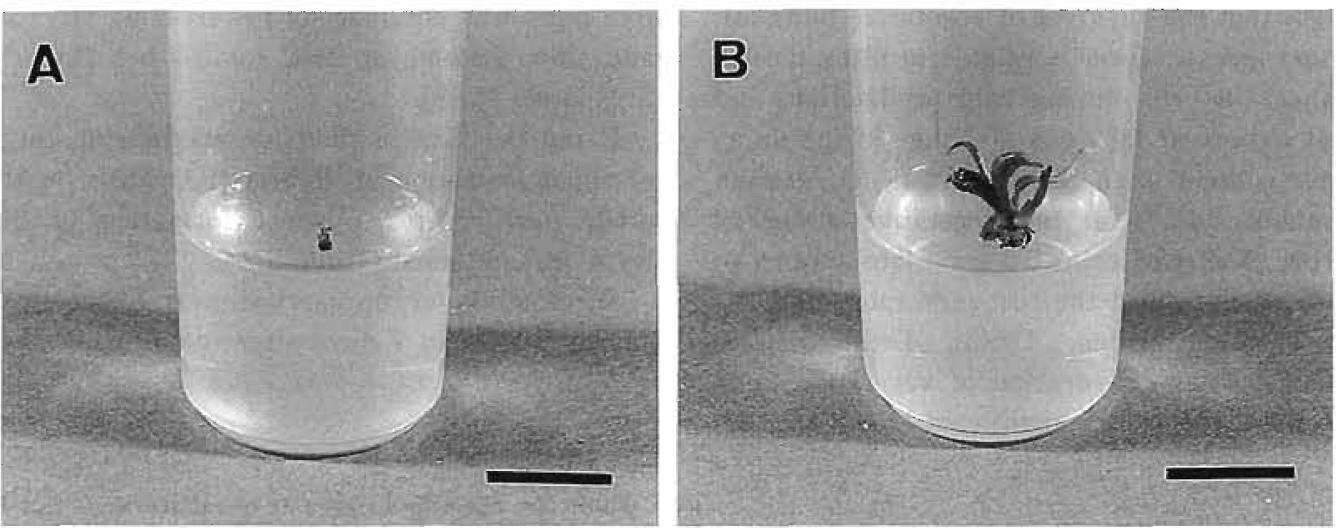

Fig. 2. Shoot formation from cryopreserved shoot tips of 'Beurré d'Amanlis' pear vegetative buds.

A: Placing of shoot tip dessected from pear winter bud on agar culture medium. (bar $=1 \mathrm{~cm}$ )

$B$ : Shoot formation of cryopreserved shoot tips at about 30 days reculturing. (bar $=1 \mathrm{~cm}$ )
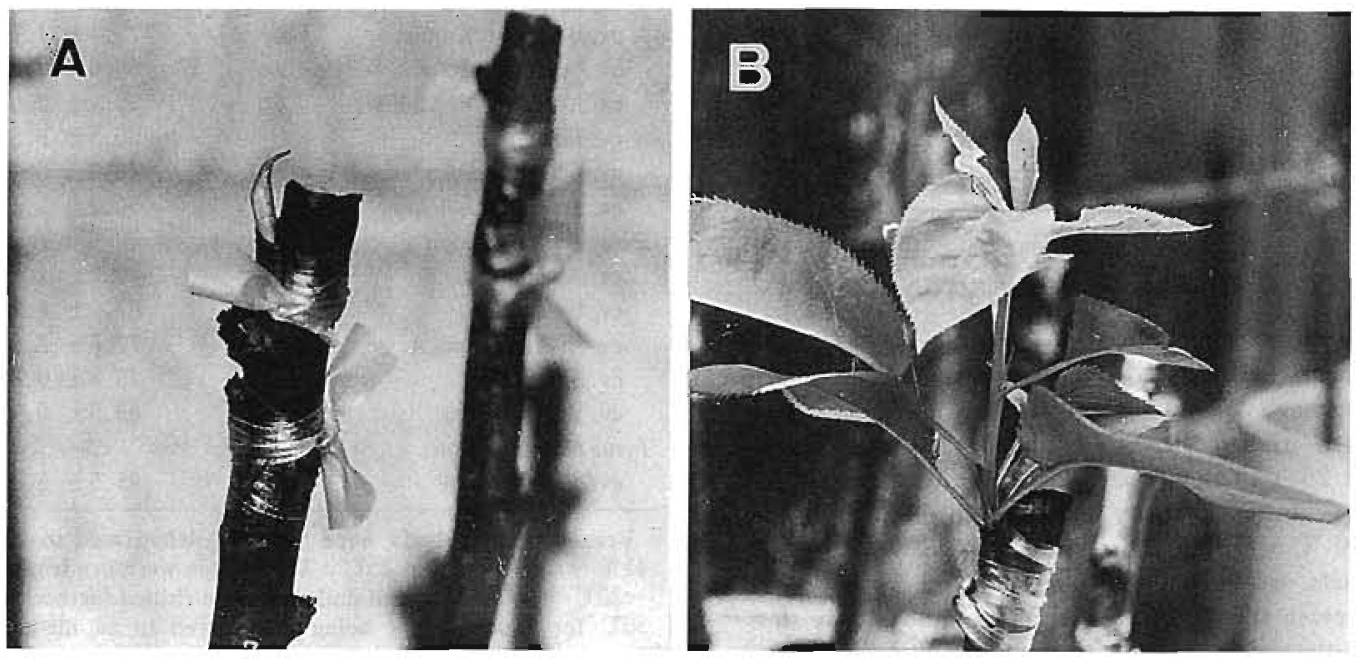

Fig. 3. Plant regenerated by micrografting. The excised buds of 'Beurré d'Amanlis' pear with vascular tissue (3 to $4 \mathrm{~mm}$ ) were micrografted onto young seedlings.

A: 3 weeks after micrografting.

B: 2 months after micrografting. 
Table 3. Effect of storage temperature in cryopereserva. tion on shoot formation of vegetative buds of 'Beurré d' Amanlis' pear.

\begin{tabular}{cc}
\hline \hline Storage temperature $\left({ }^{\circ} \mathrm{C}\right)$ & Shoot formation $(\% \pm$ S. E. $)$ \\
\hline-135 & $70.0 \pm 0$ \\
-150 & $72.5 \pm 2.5$ \\
-196 & $73.0 \pm 0.8$ \\
& NS \\
\hline
\end{tabular}

After partial dehydration, vegetative buds were pre-frozen to $-20^{\circ} \mathrm{C}$ in $5^{\circ} \mathrm{C}$ increment daily and then chilled further to $-30^{\circ} \mathrm{C}$ for 1 day. Pre-frozen buds at $-30^{\circ} \mathrm{C}$ were transfer. red to an ultra-cold freezer at $-135,-150^{\circ} \mathrm{C}$ or immersed in $\mathrm{LN}\left(-196^{\circ} \mathrm{C}\right)$. Cryopreserved buds were slowly thawed in air at $0^{\circ} \mathrm{C}$. After sterilizing, shoot tips were excised and placed on WPM containing $1.0 \mathrm{mg} \cdot \mathrm{liter}^{-1} \mathrm{BA}$ and $25 \mathrm{~g} \cdot$ liter $^{-1}$ sucrose. Approximately 20 buds were treated for each of two replicates.

NS Non-significantly different at $P<0.05$, respectively (Duncan's new multiple range test).

vegetative pear buds was only $30 \%$ because of injury to vascular tissues. Although further technical improvements are needed to obtain a higher recovery rate, the present results clearly demonstrate the feasibility of micrografting after longterm cryopreservation.

In a previous report (Oka et al., 1991), vegetative pear buds, pre-frozen to $-40{ }^{\circ} \mathrm{C}$, were successfully cryopreserved following rapid thawing in water at $37^{\circ} \mathrm{C}$, the highest rate of shoot formation of shoot tips was $50 \%$. In this study, a very high rate of shoot formation was obtained by partial dehydration of vegetative buds at $25{ }^{\circ} \mathrm{C}$ to $41 \%$ of water content which were pre-frozen to $-30{ }^{\circ} \mathrm{C}$ at a daily decrease in $5{ }^{\circ} \mathrm{C}$ increments and frozen to $-150{ }^{\circ} \mathrm{C}$, and thawed in air at $0{ }^{\circ} \mathrm{C}$. This simple cryogenic method of using vegetative buds appears promising as a routine method for cryopreservation of pear germplasm.

\section{Acknowledgements}

The authors wish to thank Dr. Masamichi Furuya (Tohoku National Agricultural Experiment Station) for supporting this work. M. Suzuki acknowledges the support of JSPS Fellowships for Young Scientists.

\section{Literature Cited}

Ishikawa, M. and A. Sakai. 1981. Freezing avoidance mechanism by supercooling in some Rhododendron flower buds with reference to water relations. Plant Cell Physiol. 22 : 953-967.

Kuroda, H. and S. Sagisaka. 1993. Ultrastructural changes in cortical cells of apple (Malus pumila. Mill.) associated with cold hardiness. Plant Cell Physiol. 34 : 357-365.

Lloyd, G. and B. McCown. 1980. Commercially feasible micropropagation of mountain laurel, Kalmia latifolia, by use of shoot tip culture. Proc. Intl. Plant Prop. Soc. $30: 421-427$.

Moriguchi, T., T. Akihama and I. Kozaki. 1985. Freeze-preservation of dormant pear shoot pieces. Japan. J. Breed. 35 : 196-199.

Niino, T., H. Yakuwa, K. Nojiri and A. Sakai. 1991. Improved procedures for the cryopreservation of mulberry using winter buds. J. Seric. Sci. Jpn. 60 : 394-399.

Niino, T., A. Sakai and H. Yakuwa. 1992. Cryopreservation of dried tips of mulberry winter buds and subsequent plant regeneration. Cryo-Letters $13: 51-58$.

Niino, T. 1993. Cryopreservation of Plant Genetic Resources. Technical Assistance Activities for Genetic Resources Projects, Ref. 6, p. 57-85. JICA, Tokyo.

Oka, S., H. Yakuwa, K. Sato and T. Niino. 1991. Survival and shoot formation in vitro of pear winter buds cryopreserved in liquid nitrogen. HortScience $26: 65-66$.

Sakai, A. 1960. Survival of the twigs of woody plants at $-196{ }^{\circ} \mathrm{C}$. Nature $185: 393-394$.

Sakai, A. and Y. Nishiyama. 1978. Cryopreservation of winter vegetative buds of hardy fruit trees in liquid nitrogen. HortScience $13: 225-227$.

Sakai, A. 1993. Cryopreservation of Plant Genetic Resources. Technical Assistance Activities for Genetic Resources Projects, Ref. 6, p. 5-26. JICA, Tokyo.

Stushnoff, C. 1987. Cryopreservation of apple genetic resources. Can. J. Plant Sci. $67:$ 1151-1154

Tyler, N. J. and C. Stushnoff. 1988. The effect of prefreezing and controlled dehydration on cryopreservation of dormant vegetative apple buds. Can. J. Plant Sci. 68 : 1163-1167.

Tyler, N. J., C. Stushnoff and L. V. Gusta. 1988. Freezing of water in dormant vegetative apple buds in relation to cryopreservation. Plant Physiol. 87 : 201-205.

Yakuwa, H. and S. Oka. 1988. Plant regeneration through meristem culture from vegetative buds of mulberry (Morus bombycis Koidz.) stored in liquid nitrogen. Ann. Bot. $62: 79-82$. 
- $150^{\circ} \mathrm{C}$ で超低温保存されたナシ冬芽のシュート形成および植物体再生

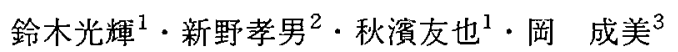

1明治大学農学部 214 神奈川県川崎市多摩区東三田 1-1-1

宸林水産省東北農業試験場 $960-21$ 福島県福島市荒井字原宿南 50

㖘林水産省宸業生物資源研究所 305 茨城県つくば市観音台 2-1-2

\begin{abstract}
摘要
セイヨウナシ冬芽（品種: 'Beurré d'Amanlis'）の超 なったままた，超低温保存した冬芽を大きめに切り出 低温保存に成功した，その方法は，採取した冬芽を予 し，直接台木に芽接ぎする方法でも個体再生できるこ 備凍結する前に, $25^{\circ} \mathrm{C}$ であらかじめ冬芽の含水率が とが明らかになった，さらに，超低温保存した'Beur$41 \%$ になるよう乾燥させ, その後予備凍結として, ré d'Amanlis' 以外のセイヨウナシおよびニホンナシ

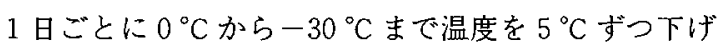
の 12 品種においても高いシュート形成率を得ること ていき，ディープフリーザー $\left(-150^{\circ} \mathrm{C}\right)$ に保存する. 再生させるには, 冬芽を $0{ }^{\circ} \mathrm{C} の$ 気相で緩慢に融解し, 滅菌処理後，茎頂を無菌的にとりだし培養する。この ができた．以上の結果から，ナシ遺伝資源の保存には， 簡便で確実性の高い冬芽を用いた超低温保存方法が利 用できると考えられた。
\end{abstract}

